\title{
IMPROVING FINANCIAL LITERACY OF THE CHILDREN AND TEENAGERS IN THE RUSSIAN FEDERATION
}

\author{
Aidar M. Tufetulov ${ }^{1}$ \\ Chulpan M. Shavaleyeva ${ }^{2}$ \\ Nadia M. Sabitova ${ }^{3}$ \\ Timur I.Abdreev ${ }^{4}$
}

\begin{abstract}
The issues of improving the financial literacy of the population are currently receiving a lot of attention both at the international and national levels. Of particular relevance are financial literacy issues for the Russian Federation. Due to the peculiarities of the country's historical development, for most citizens of Russia, issues of personal financial planning, the principles of the functioning of financial markets, the possibility of investing savings remain obscure, as a result of this, the population can not fully use modern financial products and services, does not know their rights in the financial market and unable to protect them in accordance with the law. It should be noted that the problem of a low
\end{abstract}

level of financial literacy of citizens is a problem at the national level, since a low level of financial literacy negatively affects the personal well-being of citizens, their financial potential, and accordingly prevents the development of the financial market, inhibiting investment processes in the economy. Under these conditions, increased interest in issues of financial education and financial literacy of citizens of the Russian Federation is logical and, since 2011, the World Bank and the Ministry of Finance of the Russian Federation have actively implemented a project "Promoting Improving the Level of Financial Literacy of the Population and Development of Financial Education in the Russian Federation". One of the most

\footnotetext{
${ }^{1}$ Kazan Federal University. e-mail: chulpan212@ mail.ru. Tel.: 8(917)888-80-50

${ }^{2}$ Kazan Federal University. e-mail: chulpan212@ mail.ru. Tel.: 8(917)888-80-50

${ }^{3}$ Kazan Federal University. e-mail: chulpan212@ mail.ru. Tel.: 8(917)888-80-50

${ }^{4}$ Kazan Federal University. e-mail: chulpan212@ mail.ru. Tel.: 8(917)888-80-50
} 
important areas of the project is to increase the financial literacy of children and youth. Since the start of the project, a range of training materials has been developed in this area, professional development of school teachers, teachers of orphanages, college teachers is provided, and weeks of financial literacy are held. The result of the events was a significant increase in the level of financial literacy of Russian schoolchildren. In this regard, the experience of the Russian Federation in improving financial literacy of children and youth is of great interest.

Keywords: Russian Federation, financial literacy of the population, educational programs in the field of financial literacy of children and youth

\section{Introduction}

In the modern world, the financial aspect is the most important in the life of any person. The ability to ensure their livelihoods, to form financial reserves, to save them, to effectively and safely invest in financial instruments are the basic skills of citizens whose development is given increased attention in developed and developing countries. Since 2003, in the world practice, the Organization for Economic Cooperation and Development (OECD) has been dealing with issues of financial education of citizens. The main reasons for increasing attention to the financial education of the population were named:

1) uncertainty and complexity in the work of the financial sector of the economy;

2) low level of financial literacy of citizens in all countries;

3) increasing the financial risks of citizens in connection with an increase in their income and investment in financial instruments, increasing their individual responsibility for actions in the financial market.

Subsequently, the need to improve the financial literacy of citizens was noted by other international organizations. 


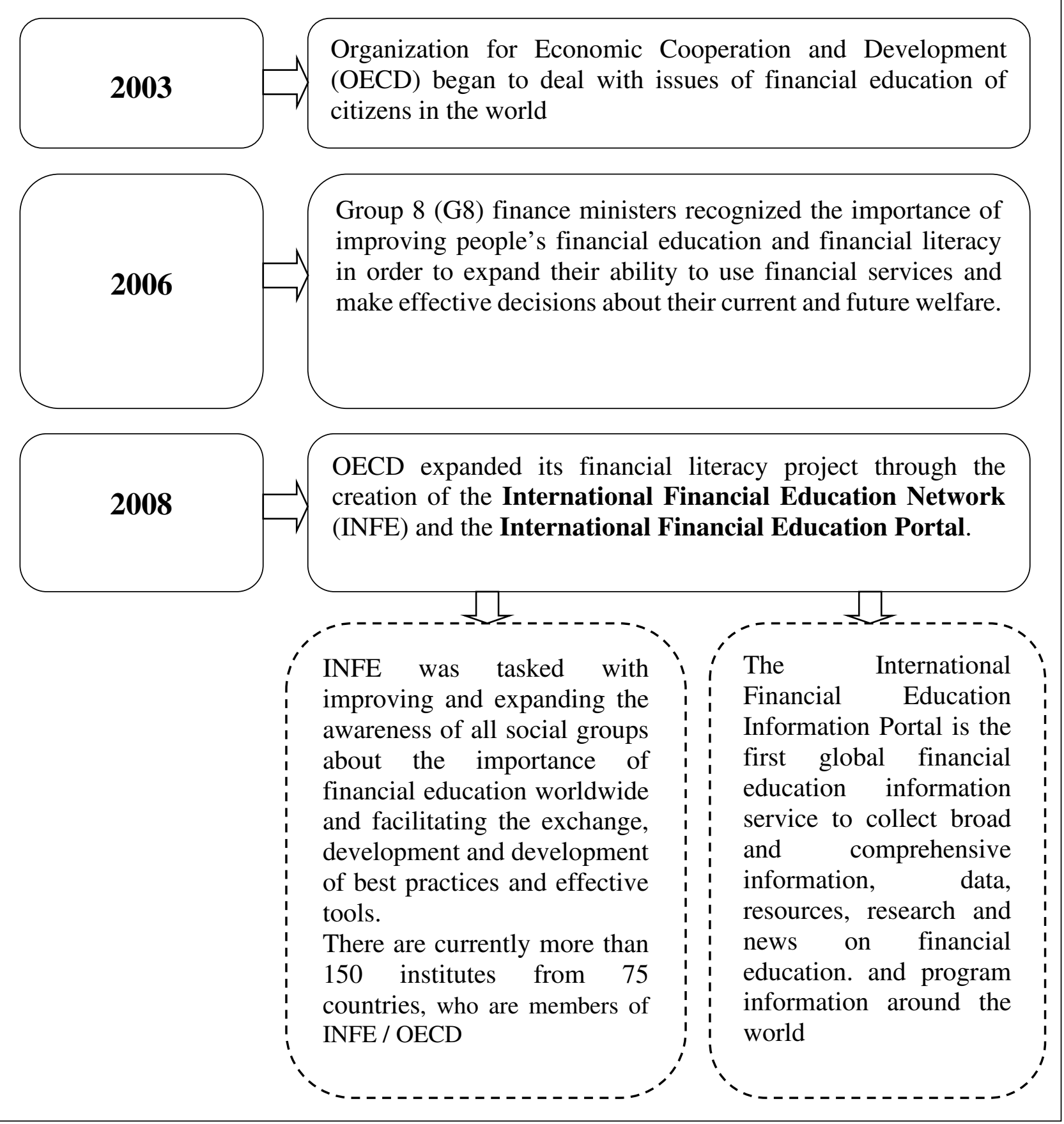

Figure 1. Development of projects aimed at improving the financial literacy of the population at the international level

Currently, issues of improving the financial literacy of citizens are an element of state policy in many countries
- the USA, Canada, Australia, Great

Britain, France, Poland, etc. 


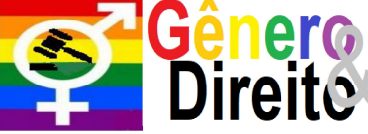

In 2009, the Government of the

Russian Federation approved the Concept of the National Program for increasing the level of financial literacy of the population of the Russian Federation, which outlined the need to increase the level of financial literacy of Russian citizens, due to:

- the inability of the population to make a balanced decision based on the analysis of all available information regarding the use of certain financial products or services;

- the inability of the population to adequately assess risks in the financial markets;

- insufficient awareness of citizens about the possibilities of investing and conducting operations in the financial markets;

- lack of knowledge in the field of consumer protection in the financial markets;

- Inaccessibility for most citizens of professional financial advice.

In order to implement the Concept in 2011, the World Bank and the Ministry of Finance of the Russian Federation signed a loan agreement in the amount of $\$ 113$ million for the implementation of the joint project
"Promoting the level of financial literacy of the population and the development of financial education in the Russian Federation", which laid the foundations measures aimed at improving the financial literacy of citizens.

Project activities focus on four categories of citizens:

1) schoolchildren;

2) students studying in noneconomic specialties;

3) adult population;

4) pensioners.

Particular attention is paid to improving the financial literacy of children and youth, since this helps to form financially literate citizens who are freely oriented in the financial market.

\section{Methods}

Based on empirical research methods, the article describes and evaluates the implementation of a project in Russia aimed at improving the financial literacy of children and youth. The information base for writing the article was data from the Ministry of Finance of the Russian Federation, National Research University Higher School of Economics, Kazan Federal University. 


\section{Results And Discussion}

Improving the financial literacy of children and youth has become one of the most important areas of the project "Promoting the improvement of the level of financial literacy of the population and the development of financial education in the Russian Federation". The main idea of this direction of the project is the training of teachers of educational organizations in order to further educate children in the educational process. It should be noted that individual lessons in financial literacy are not provided for by curricula; in this regard, elements of financial literacy are included in various disciplines, mainly social studies and mathematics. Much attention is paid to teaching financial literacy in the lower grades.

In order to implement the project in terms of improving the financial literacy of children, the Federal Methodological Center was created at the National Research University Higher School of Economics, the purpose of which is to increase the financial literacy of school teachers, orphanage teachers and college teachers. To ensure the achievement of this goal, the Federal Methodological Center:
1) financial literacy training materials developed

2) 11 interregional methodological centers have been created to improve the skills of teachers in schools and colleges.

Before developing training materials on financial literacy, specialists from the Ministry of Finance of the Russian Federation and the Federal Methodological Center studied international experience and determined the competencies that schoolchildren should have. Based on this, the materials were published on the website of the Federal Methodological Center, which everyone can use for free. The set of training materials includes more than 80 books for different target groups of students:

- students in grades 2-4 (7-10 years);

- students in grades 5-9 (11-15 years);

- students of grades 10-11 (1618 years);

- college students;

- Pupils of orphanages.

In addition, thematic modules on the most interesting topics of financial literacy were prepared: "Banks", 
"Insurance", "Financial Security", "Stock Market", “Own Business", etc.

Each set of training materials includes several manuals:

- materials for students;

- guidelines for teachers of

financial literacy;

- materials for parents, which provide recommendations on the financial education of children in the family.

The peculiarity of training materials on financial literacy is that the training is based on the study of practical situations: planning personal income and expenses, the correct investment of savings, assessing the need to obtain a loan, choosing the right financial product, protecting the right if they are violated in the financial market, etc.

Published financial literacy training materials will be distributed in Russian regions with a total circulation of over 8 million copies.

Interregional methodological centers created to implement the project in terms of improving the financial literacy of children provide continuing education for school teachers, orphanage teachers and college teachers in more than 40 regions of the Russian
Federation under the program "Content and Methods of Teaching Financial Literacy to Various Categories of Students". The teacher development program includes consideration of the following aspects:

1) features and methods of teaching financial literacy to children of different age groups, the possibility of including elements of financial literacy in various disciplines;

2) basics of financial literacy:

- personal finances and savings;

- issues of taxation of citizens;

- state and non-state pension provision;

- lending;

- investment products;

- insurance;

- business basics

- consumer rights Protection;

- financial fraud and others.

For 2016-2019, 13240 teachers of educational institutions of Russia were trained by the Interregional Methodological Centers, of which 3069 were teachers of grades 2-4, 5343 were teachers of grades 5-9, 3162 were teachers of grades 10-11, 250 were teachers of orphanages, 1416 - college teachers. 
The general scheme for organizing the implementation of the project "Promoting Improving the Level of Financial Literacy of the Population
66

and Developing Financial Education in the Russian Federation" in terms of improving the financial literacy of children is presented in Figure 2.

Federal Methodological Center, created by National Research University Higher School of Economics

Development of a set of training materials on financial literacy, which is distributed in educational organizations and posted on the website of the Federal Methodological Center (free access)
Interregional methodological centers provide advanced training for school teachers, teachers of orphanages and college teachers in more than 40 regions of Russia

Trained educators teach financial literacy in their educational institutions, using, among other things, teaching materials developed by the Federal Methodological Center

Figure 2. Organization chart for the implementation of the project "Promoting the level of financial literacy of the population and the development of financial education in the Russian Federation" in terms of improving the financial literacy of children.

In addition to classes held in educational institutions, children and adolescents to increase their financial literacy can use: 
1) resources posted on a specially created portal "Your Finance", on which there are specially developed materials in the form of booklets, comics, videos, articles;

2) events held annually weeks of financial literacy for children and youth. Over 4 years, the total number of participants in the week of financial literacy in Russia exceeded 5 million people.

\section{Summary}

The system of increasing the financial literacy of children and youth in the Russian Federation was created taking into account international experience and the special organization of the educational process. The uniqueness and importance of the ongoing project is that:

1) one-time training of teachers gives a long-term effect, since teachers repeatedly bring information to students and, importantly, to different generations of students;

2) teachers working in orphanages are practically the only way to ensure financial education for the most vulnerable categories - orphans and children left without parental care;
3) with the help of teachers, you can increase the financial literacy of parents by inviting them to open lessons and devoting time to specific topics at parent meetings.

The result of the events was an increase in the level of financial literacy of Russian schoolchildren. According to an international study by the Organization for Economic Cooperation and Development within the framework of the International Program for the Assessment of Educational Achievements of Students (PISA-2015), Russian 15-year-old students took 4th place in financial literacy, significantly improving performance in 2012, rising from 10th place.

\section{Conclusions}

Thus, within the framework of the Project, a large number of various educational and methodological materials have been created for teaching schoolchildren and students of financial literacy colleges. Educational organizations have the opportunity to choose the most suitable forms and means of introducing financial literacy into the educational program: to train 
schoolchildren or students only within the framework of compulsory subjects or through additional education at school and college. However, the results achieved are not grounds for paying less attention to issues of increasing the financial literacy of citizens. The need for further implementation of the project "Promoting the level of financial literacy of the population and the development of financial education in the Russian Federation" is not in doubt, since the experience already existing in Russia of the implementation of this project confirms its importance and significance.

\section{Acknowledgements}

The work is performed according to the Russian Government Program of Competitive Growth of Kazan Federal University.

\section{Bibliography}

J. Bayuk, S.A.Altobello, "Can gamification improve financial behavior? The moderating role of app expertise", 2019, International Journal of Bank Marketing, Issue 37(4), pp. 951975
N.V. Dulina, D.V. Moiseeva, Financial literacy as a result of the process of financial education (on the example of Volgograd region),

P. Farías, "Determinants of knowledge of personal loans' total costs: How price consciousness, financial literacy, purchase recency and frequency work together", 2019, Journal of Business Research, Issue 102, pp.212-2019

K.Karakurum-Ozdemir, M.Kokkizil, G. Uysal, "Financial Literacy in Developing Countries", 2019, Social Indicators Research, Issue 143(1), pp. 325-353

K.T.Kim, , S.G.Anderson, M.C. "Financial Knowledge and Short-Term and Long-Term Financial Behaviors of Millennials in the United States", 2019, Journal of Family and Economic Issues, Issue 40(2), pp. 194-208

R. Kuntze, C.Wu, B.R.Wooldridge, Y.$\mathrm{O}$ "Whang, "Improving financial literacy in college of business students: modernizing delivery tools", 2019, International Journal of Bank Marketing, Issue 37(4), pp. 976-990 
A. Lusardi, "Financial literacy and the need for financial education: evidence and implications", 2019, Swiss Journal of Economics and Statistics, Issue 155(1) L.Nadolny, , J.Nation, J.Fox, "Supporting motivation and effort persistence in an online financial literacy course through game-based learning", 2019, International Journal of GameBased Learning, Issue 9(3), pp. 38-52

M.F.Pang, "Enhancing the generative learning of young people in the domain of financial literacy through learning study", 2019, International Journal for Lesson and Learning Studies, Issue 8(3), pp. 170-182

Official website of The Organization for Economic Co-operation and Development, 2019. - Access mode: http://www.oecd.org

Official website of the Federal methodical center, 2019 - Access mode: https://fmc.hse.ru/ 